\title{
Early onset torsion dystonia (Oppenheim's dystonia) Christoph Kamm*
}

Address: Department of Neurodegenerative Diseases, Hertie-Institute for Clinical Brain Research, University of Tübingen, Hoppe-Seyler Str. 3, 72076 Tübingen, Germany

Email: Christoph Kamm* - christoph.kamm@uni-tuebingen.de

* Corresponding author

Published: 27 November 2006

Orphanet Journal of Rare Diseases 2006, I:48 doi:I0.1 I86/I750-I I72-I-48

This article is available from: http://www.OJRD.com/content/l///48

(c) 2006 Kamm; licensee BioMed Central Ltd.

This is an Open Access article distributed under the terms of the Creative Commons Attribution License (http://creativecommons.org/licenses/by/2.0), which permits unrestricted use, distribution, and reproduction in any medium, provided the original work is properly cited.
Received: II October 2006

Accepted: 27 November 2006

\begin{abstract}
Early onset torsion dystonia (EOTD) is a rare movement disorder characterized by involuntary, repetitive, sustained muscle contractions or postures involving one or more sites of the body. A US study estimated the prevalence at approximately I in 30,000. The estimated prevalence in the general population of Europe seems to be lower, ranging from I in 330,000 to I in 200,000, although precise numbers are currently not available. The estimated prevalence in the Ashkenazi Jewish population is approximately five to ten times higher, due to a founder mutation. Symptoms of EOTD typically develop first in an arm or leg in middle to late childhood and progress in approximately $30 \%$ of patients to other body regions (generalized dystonia) within about five years. Distribution and severity of symptoms vary widely between affected individuals. The majority of cases from various ethnic groups are caused by an autosomal dominantly inherited deletion of 3 bp (GAG) in the DYTI gene on chromosome $9 \mathrm{q} 34$. This gene encodes a protein named torsinA, which is presumed to act as a chaperone protein associated with the endoplasmic reticulum and the nuclear envelope. It may interact with the dopamine transporter and participate in intracellular trafficking, although its precise function within the cell remains to be determined. Molecular genetic diagnostic and genetic counseling is recommended for individuals with age of onset below 26 years, and may also be considered in those with onset after 26 years having a relative with typical early onset dystonia. Treatment options include botulinum toxin injections for focal symptoms, pharmacological therapy such as anticholinergics (most commonly trihexiphenydil) for generalized dystonia and surgical approaches such as deep brain stimulation of the internal globus pallidus or intrathecal baclofen application in severe cases. All patients have normal cognitive function, and despite a high rate of generalization of dystonia, $75 \%$ of those patients are able to maintain ambulation and independence, and therefore a comparatively good quality of life, with modern treatment modalities.
\end{abstract}

\section{Disease name and synonyms}

Early onset torsion dystonia

Oppenheim's dystonia

Dystonia musculorum deformans

\section{Definition}

Early onset torsion dystonia (EOTD) is characterized by involuntary, repetitive, sustained muscle contractions or postures, typically of the limbs, which may spread to other body parts, in the absence of other neurological abnormalities. It is inherited in an autosomal dominant 
fashion with a penetrance of only $30-40 \%$ [1], suggesting that various genetic and/or environmental factors contribute to development of the disease. The majority of cases are caused by a deletion of 3 bp (GAG) in the DYT1 gene on chromosome 9q34.

The term "Dystonia" in general refers to a large diverse group of movement disorders involving involuntary muscle contractions or postures. It may be classified in three ways:

(1) clinically, i.e. according to age at onset or distribution of affected body regions;

(2) etiologically, i.e. into primary, secondary, dystoniaplus or heredodegenerative;

(3) genetically, with 15 loci described to date.

\section{Diagnostic criteria}

The following diagnostic criteria have been established for EOTD [1-3]:

\section{Definite dystonia}

Characteristic overt twisting or directional movements and postures that are consistently present.

\section{Probable dystonia}

Postures or movements suggestive of dystonia that are insufficient in intensity or consistency to merit classification as definite (e.g. excessively tense and labored writing with minimal posturing, flurries of blinking but no episodes of sustained closure, etc.).

\section{Possible dystonia}

Muscle contractions not considered abnormal but remotely suggestive of dystonia (e.g. unusual hand grip with mild excess hand tension but normal flowing handwriting, increased blinking with no flurries or sustained contractions, etc.).

Only the category of "definite dystonia" was shown to be $100 \%$ specific in DYT1 families [3], suggesting that only those patients with definite signs of dystonia should be considered affected in genetic research studies.

\section{Epidemiology}

EOTD is a rare disease, with an estimated prevalence of 3.4:100,000 and annual incidence of 0.2:100,000 in Rochester, Minnesota [4]. The prevalence in the Ashkenazi Jewish (AJ) population is estimated to be five to ten times higher [5], due to a founder mutation which appears to have arisen approximately 350 years ago in Byelorussia/Lithuania [6]. The frequency of the DYT1 GAG deletion in the AJ population is high, between
1:2000 and 1:6000. In contrast, the prevalence in the general population of Europe seems to be lower. Estimates range from 0.3 to $0.5: 100,000$ although precise numbers are currently not available.

\section{Clinical description}

EOTD is characterized by involuntary, repetitive, sustained muscle contractions or postures involving one or more sites of the body. Typically, symptoms develop first in an arm or leg in middle to late childhood (mean age of onset: 12.5 years) [7] and progress in approximately $30 \%$ of patients to other body regions (generalized dystonia) within about five years [8]. "Torsion" refers to the twisting nature of body movements observed in EOTD, often affecting the trunk. Patients may be severely physically incapacitated, but are normal intellectually and show no other neurological symptoms. Distribution and severity of symptoms vary widely between affected individuals, ranging from mild focal dystonia, e.g. writer's cramp [9] to severe generalized dystonia, even within families [10]. Earlier age of onset and onset in the legs predicts a more severe clinical course, i.e. development of generalized dystonia $[11,12]$.

The DYT1 GAG deletion is responsible for the majority of typical early onset dystonia cases of diverse ethnic origins, whether inherited or caused by a de novo mutation, whereas only a small minority of patients with atypical, e.g. focal dystonia, harbor this mutation [7,13-18]. If mutant gene carriers pass the age of approximately 28 years without developing symptoms, they usually escape the disease for life.

\section{Etiology}

Neuropathologically, EOTD is characterized by a lack of neurodegeneration, suggesting that neuronal dysfunction, rather than loss of neurons, underlies disease symptoms. However, cell bodies of dopaminergic neurons appear to be enlarged in brains from dystonia patients [19]. In the brains of four DYT1 patients, perinuclear inclusion bodies in specific brainstem areas (pedunculopontine nucleus, periaqueductal gray) have been reported [20]. These findings have been recapitulated in two different DYT1 animal models, both in transgenic mice overexpressing human mutant $\triangle \mathrm{E}$-torsinA [21] and in male DYT1 $\triangle$ GAG knockin mice [22]. Despite the low penetrance of only 30-40\% for clinical symptoms, functional imaging studies found metabolic hyperactivity in the lentiform nuclei, cerebellum and supplemental motor areas, and impaired sequence learning in both manifesting and non-manifesting carriers of the DYT1 GAG deletion, indicating that penetrance of the GAG deletion is greater than that assumed based on clinical grounds $[23,24]$. In addition, a recent study found that striatal $D_{2}$ receptor binding was reduced in non-manifesting carriers of the DYT1 GAG 
deletion. This reduction may be a trait feature of DYT1 dystonia, with other factors being necessary for manifestation of the signs and symptoms. Alternatively, clinical penetrance may be linked to the extent of the decrease in striatal $\mathrm{D}_{2}$ receptor binding [25].

The DYT1 gene encodes the torsinA protein. TorsinA is an endoplasmic reticulum/nuclear envelope (NE) ATPdependent chaperone protein $[26,27]$ involved in intracellular trafficking [28]. Mutant $\Delta \mathrm{E}$-torsinA relocalizes to the NE $[27,29,30]$, and postmigratory neurons from both torsinA null and homozygous mutant knock-in mice develop membrane abnormalities of the NE [31]. In addition, recent studies in mammalian cell lines have shown that overexpression of wild-type torsinA appears to regulate the intracellular trafficking of the dopamine transporter, whereas overexpression of mutant $\Delta$ EtorsinA had no effect. These results establish a potential link between torsinA and the dopaminergic system [59].

Several lines of evidence suggest that the disease is caused by a dysfunction of the basal ganglia: (1) Although torsinA is ubiquitously expressed, expression levels within the human brain are highest within dopaminergic neurons of the substantia nigra [32]; (2) Striatial [18F]dopa uptake is mildly reduced in manifesting DYT1 GAG deletion carriers [33]; (3) An increase in the ratio of dopamine metabolites to dopamine was found in the postmortem striatum of DYT1 dystonia brains as compared to controls [34]; (4) A phenotypically similar form of inherited dystonia, dopa-responsive dystonia (DRD), is caused by insufficient synthesis of dopamine $[35,36]$, and symptomatic dystonia frequently affects patients with acquired lesions of the basal ganglia (e.g. stroke) $[37,38]$.

\section{Diagnostic methods}

Molecular genetic diagnostic in conjunction with genetic counseling is recommended for individuals with age of onset below 26 years, and may also be considered in those with onset after 26 years having a relative with typical early onset dystonia [7].

\section{Differential diagnosis}

Differential diagnosis includes other forms of primary dystonia and disorders in which dystonia is one of several neurological conditions present. The second large and diverse group includes the dystonia-plus syndromes, the heredodegenerative dystonias, the secondary ("symptomatic") dystonias, other dystonia-like conditions, and early-onset parkinsonism.

Other forms of primary dystonia (DYT2, 4, 6, 7 and I3) The phenotype of DYT2 dystonia, an autosomal recessive form of dystonia, resembles early onset torsion dystonia (DYT1) in three of the four families reported to date (early onset of symptoms, frequently in the feet, followed by rapid generalization) $[39,40]$. However, there is a debate as to whether the mode of inheritance in these families is actually autosomal recessive or autosomal dominant with reduced penetrance [41].

The DYT4 locus has been assigned to an Australian family with predominant whispering dysphonia and additional variable dystonic symptoms [42,43], clearly different phenotypically from classical DYT1 dystonia.

DYT6 refers to another autosomal dominant form of dystonia of mixed-type described in two German-Mennonite families [44]. In contrast to DYT1 dystonia, the average age at onset in these families was higher ( 18.6 years, range 5-38), and in many patients dystonic symptoms were predominantly cranio-cervical, with progression to generalized dystonia in only a few cases.

DYT7 refers to a locus for adult-onset focal, predominantly cervical dystonia mapped in a German family [45].

The DYT13 locus has been mapped in a non-Jewish Italian family [46] with mostly segmental dystonia with prominent cranio-cervical and arm involvement, more closely resembling the DYT6 than the DYT1 phenotype.

\section{Dystonia-plus (DYT5, DYTI I and DYTI2)}

Dystonia-plus refers to conditions in which dystonia is one of only two neurological abnormalities present, the other usually being either parkinsonism or myoclonus. This group includes Dopa-Responsive Dystonia (DRD, DYT5), Myoclonus-Dystonia (DYT11) and Rapid Onset Dystonia-Parkinsonism (DYT12).

\section{Heredodegenerative dystonias (DYT3 and others)}

In heredodegenerative dystonias, dystonia is part of a more widespread neurodegenerative syndrome, often with known inheritance, and may or may not be a prominent feature. This large group includes X-linked Dystonia-Parkinsonism ("Lubag", DYT3), Idiopathic Parkinson's Disease (IPD), Multiple System Atrophy (MSA), Progressive Supranuclear Palsy (PSP), Hallervorden-Spatz Disease, Wilson's disease, Rett syndrome, Neuroacanthocytosis, and many others.

\section{Secondary dystonia}

Secondary (symptomatic) dystonias are caused by environmental insults such as stroke, tumors, infections, drugs and toxins or by metabolic disorders (e.g. homocysteinuria, metachromatic leukodystrophy, Lesch-Nyhan syndrome, and others). 
Other dystonia-like conditions (DYT8, DYT9, and DYTI0) This group includes conditions mimicking symptoms of dystonia (e.g. psychogenic dystonia or pseudodystonia) and paroxysmal disorders, such as paroxysmal nonkinesigenic dystonia (PNKD, DYT8), paroxysmal choreoathetosis with episodic ataxia and spasticity (DYT9), paroxysmal kinesigenic dystonia (PDK, DYT10), and others.

\section{Early onset parkinsonism}

A considerable proportion of early onset Parkinson's disease, with onset of symptoms before 40 years of age, is caused by mutations in the Parkin gene [47] and frequently presents with dystonia, especially in the lower limbs [48]. Thus, this condition should be considered in the differential diagnosis of EOTD.

\section{Genetic counseling}

Based on a systematic genetic and clinical analysis of 267 individuals with primary torsion dystonia, including Ashkenazi Jewish and non-Jewish patients, diagnostic DYT1 testing in conjunction with genetic counseling is recommended for individuals with an age of onset below 26 years, and may also be considered in those with onset after 26 years having a relative with typical EOTD [7]. Genetic counseling should take into account that DYT1 dystonia is inherited in an autosomal dominant manner with a low penetrance of $30-40 \%$ and great clinical variability. Few cases of de novo mutations have been reported $[49,50]$. Asymptomatic adult relatives should be informed before testing that onset of DYT1 dystonia after age 26 is very unlikely, and that, if it occurs, symptoms are usually mild and unlikely to progress [7]. Testing of asymptomatic at-risk individuals during childhood is not recommended. In addition to prenatal testing through chorionic villus sampling, preimplantation genetic diagnosis has recently been reported [51].

\section{Management including treatment Drug therapy}

As DRD (DYT5) is phenotypically very similar to EOTD, but its symptoms, in contrast to EOTD, typically respond very well to dopaminergic therapy, it is recommended that every patient with early onset focal dystonia (onset below 26 years) be given a trial of L-Dopa/decarboxylase inhibitor, starting with $1 \mathrm{mg} / \mathrm{kg}$ per day of levodopa and slowly increasing until complete benefit is achieved or dose-limiting side effects appear. Most DRD patients respond well to $4-5 \mathrm{mg} / \mathrm{kg}$ per day [52].

In general, drug therapy in EOTD is not very effective. Anticholinergics, especially in a high dosage (e.g. trihexiphenydil up to 30-60 mg/day), are the only substance class for which controlled studies are available [53]. Dosage should be increased very slowly to prevent side effects such as cognitive or memory deficits, which are frequently dose-limiting, although children can generally tolerate much higher doses than adults. Other substances, which may or may not be effective, include baclofen, benzodiazepines such as diazepam or clonazepam, pimozid or tetrabenazin. In severe cases of segmental or generalized dystonia, especially of the lower body and trunk, intrathecal baclofen administration may be considered [54].

\section{Botulinum toxin injections}

Independent of genetic background, local botulinum toxin injections directly into affected muscles now represent the first line treatment of focal dystonias (reviewed in [55]). Therefore, botulinum toxin injections by trained movement disorder specialists may be a useful therapy for selected muscle groups in EOTD, such as neck muscles for torticollis, facial muscles for blepharospasm or hand/arm muscles for writer's cramp. If successful, the injections need to be repeated on a regular basis (usually every 3-6 months).

\section{Surgical approaches}

Due to technical advances in recent years, interest in functional surgical approaches in dystonia has been renewed, in particular deep brain stimulation (DBS) of the globus pallidus and pallidotomy (reviewed in [56]). Although experience with this approach is still limited, preliminary results in patients with primary generalized dystonia, especially DYT1 GAG deletion carriers, are very promising [57]. Therefore, DBS may be helpful in selected EOTD patients with severe generalized dystonia.

\section{Prognosis}

Only few studies on the natural history of EOTD in genetically confirmed patients have been conducted. In one report following the clinical course of 33 patients from Israel [58], 63.6\% had progressed into generalized dystonia after a mean of $15.5+/-13.8$ years of symptoms, $15 \%$ were wheelchair-bound and $9 \%$ were using walking aids. All patients had normal cognitive function. Despite the high rate of generalization, $75 \%$ of those patients were able to maintain ambulation and independence, and therefore a comparatively good quality of life, with modern treatments combining drugs, botulinum toxin and functional neurosurgery.

\section{Unresolved questions}

Very little is known yet about the normal cellular function of the torsinA protein. Further studies are required to address how mutant torsinA causes neuronal dysfunction, and how this mutation leads to a dominantly inherited disease with a markedly low penetrance and a very selective neurological phenotype. Since the age of onset is associated with a period of motor learning and high synaptic plasticity, a possible role of torsinA in coordinated neuronal development merits further investigation. In addition, 
further evidence for or against direct involvement of the dopaminergic system in EOTD is warranted.

\section{References}

I. Bressman SB, de Leon D, Brin MF, Risch N, Burke RE, Greene PE, Shale H, Fahn S: Idiopathic dystonia among Ashkenazi Jews: evidence for autosomal dominant inheritance. Ann Neurol 1989, 26:612-620.

2. Cassetta E, Del Grosso N, Bentivoglio AR, Valente EM, Frontali M, Albanese A: Italian family with cranial cervical dystonia: clinical and genetic study. Mov Disord 1999, I 4:820-825.

3. Bressman SB, Raymond D, Wendt K, Saunders-Pullman R, De Leon $D$, Fahn S, Ozelius L, Risch N: Diagnostic criteria for dystonia in DYTI families. Neurology 2002, 59:1780-1782.

4. Nutt JG, Muenter MD, Aronson A, Kurland LT, Melton LJ 3rd: Epidemiology of focal and generalized dystonia in Rochester, Minnesota. Mov Disord 1988, 3:188-194.

5. Zeman W, Dyken P: Dystonia musculorum deformans. Clinical, genetic and pathoanatomical studies. Psychiatr Neurol Neurochir 1967, 70:77-121.

6. Risch N, de Leon D, Ozelius L, Kramer P, Almasy L, Singer B, Fahn S, Breakefield X, Bressman S: Genetic analysis of idiopathic torsion dystonia in Ashkenazi Jews and their recent descent from a small founder population. Nat Genet 1995, 9: I52-I59.

7. Bressman SB, Sabatti C, Raymond D, de Leon D, Klein C, Kramer PL, Brin MF, Fahn S, Breakefield X, Ozelius LJ, Risch NJ: The DYT I phenotype and guidelines for diagnostic testing. Neurology 2000 , 54: $1746-1752$.

8. Greene P, Kang UJ, Fahn S: Spread of symptoms in idiopathic torsion dystonia. Mov Disord 1995, 10:143-I52.

9. Gasser T, Windgassen K, Bereznai B, Kabus C, Ludolph AC: Phenotypic expression of the DYTI mutation: a family with writer's cramp of juvenile onset. Ann Neurol 1998, 44: I26-I28.

10. Opal P, Tintner R, Jankovic J, Leung J, Breakefield XO, Friedman J, Ozelius L: Intrafamilial phenotypic variability of the DYTI dystonia: from asymptomatic TORIA gene carrier status to dystonic storm. Mov Disord 2002, I 7:339-345.

II. Marsden CD: Investigation of dystonia. Adv Neurol 1988, 50:35-44.

12. Burke RE, Brin MF, Fahn S, Bressman SB, Moskowitz C: Analysis of the clinical course of non-Jewish, autosomal dominant torsion dystonia. Mov Disord 1986, I:163-178.

13. Kamm C, Castelon-Konkiewitz E, Naumann M, Heinen F, Brack M, Nebe A, Ceballos-Baumann A, Gasser T: GAG deletion in the DYT I gene in early limb-onset idiopathic torsion dystonia in Germany. Mov Disord 1999, I 4:681-683.

14. Ozelius LJ, Hewett JW, Page CE, Bressman SB, Kramer PL, Shalish C, de Leon D, Brin MF, Raymond D, Corey DP, Fahn S, Risch NJ, Buckler AJ, Gusella JF, Breakefield XO: The early-onset torsion dystonia gene (DYTI) encodes an ATP-binding protein. Nat Genet 1997, I 7:40-48.

15. Valente EM, Warner TT, Jarman PR, Mathen D, Fletcher NA, Marsden $C D$, Bhatia KP, Wood NW: The role of DYTI in primary torsion dystonia in Europe. Brain 1998, I 2 I ( Pt I 2):2335-2339.

16. Klein C, Friedman J, Bressman S, Vieregge P, Brin MF, Pramstaller PP, De Leon D, Hagenah J, Sieberer M, Fleet C, Kiely R, Xin W, Breakefield XO, Ozelius LJ, Sims KB: Genetic testing for early-onset torsion dystonia (DYTI): introduction of a simple screening method, experiences from testing of a large patient cohort, and ethical aspects. Genet Test 1999, 3:323-328.

17. Kamm C, Naumann M, Mueller J, Mai N, Riedel L, Wissel J, Gasser T: The DYT I GAG deletion is infrequent in sporadic and familial writer' s cramp. Mov Disord 2000, I 5: | 238-I24 I.

18. Grundmann K, Laubis-Herrmann U, Bauer I, Dressler D, VollmerHaase J, Bauer P, Stuhrmann M, Schulte T, Schols L, Topka H, Riess $O$ : Frequency and phenotypic variability of the GAG deletion of the DYTI gene in an unselected group of patients with dystonia. Arch Neurol 2003, 60:1266-1270.

19. Rostasy K, Augood SJ, Hewett JW, Leung JC, Sasaki H, Ozelius LJ, Ramesh V, Standaert DG, Breakefield XO, Hedreen JC: TorsinA protein and neuropathology in early onset generalized dystonia with GAG deletion. Neurobiol Dis 2003, I 2: | |-24.

20. McNaught KS, Kapustin A, Jackson T, Jengelley TA, Jnobaptiste $R$ Shashidharan P, Perl DP, Pasik P, Olanow CW: Brainstem pathol- ogy in DYTI primary torsion dystonia. Ann Neurol 2004, 56:540-547.

21. Shashidharan P, Sandu D, Potla U, Armata IA, Walker RH, McNaught KS, Weisz D, Sreenath T, Brin MF, Olanow CW: Transgenic mouse model of early-onset DYTI dystonia. Hum Mol Genet 2005, I 4: I25-I33.

22. Dang MT, Yokoi F, McNaught KS, Jengelley TA, Jackson T, Li J, Li Y: Generation and characterization of Dyt I DeltaGAG knockin mouse as a model for early-onset dystonia. Exp Neurol 2005 , 196:452-463.

23. Eidelberg D, Moeller JR, Antonini A, Kazumata K, Nakamura T, Dhawan $V$, Spetsieris $P$, deLeon D, Bressman SB, Fahn S: Functional brain networks in DYTI dystonia. Ann Neurol 1998, 44:303-3 I 2.

24. Ghilardi MF, Carbon M, Silvestri G, Dhawan V, Tagliati M, Bressman $\mathrm{S}$, Ghez C, Eidelberg D: Impaired sequence learning in carriers of the DYTI dystonia mutation. Ann Neurol 2003, 54: I02-109.

25. Asanuma K, Ma Y, Okulski J, Dhawan V, Chaly T, Carbon M, Bressman SB, Eidelberg D: Decreased striatal D2 receptor binding in non-manifesting carriers of the DYTI dystonia mutation. Neurology 2005, 64:347-349.

26. Breakefield $\mathrm{XO}, \mathrm{Kamm} \mathrm{C}$, Hanson $\mathrm{PI}$ : TorsinA: movement at many levels. Neuron 200I, 3 I:9-I 2.

27. Naismith TV, Heuser JE, Breakefield $X O$, Hanson PI: TorsinA in the nuclear envelope. Proc Natl Acad Sci U S A 2004, I 0 I:76I 2-76I7.

28. Kamm C, Boston H, Hewett J, Wilbur J, Corey DP, Hanson PI, Ramesh V, Breakefield XO: The early onset dystonia protein torsinA interacts with kinesin light chain I. J Biol Chem 2004, 279(19): 19882-19892.

29. Goodchild RE, Dauer WT: Mislocalization to the nuclear envelope: an effect of the dystonia-causing torsinA mutation. Proc Natl Acad Sci U S A 2004, I 0 I:847-852.

30. Bragg DC, Camp SM, Kaufman CA, Wilbur JD, Boston H, Schuback DE, Hanson PI, Sena-Esteves M, Breakefield XO: Perinuclear biogenesis of mutant torsin-A inclusions in cultured cells infected with tetracycline-regulated herpes simplex virus type I amplicon vectors. Neuroscience 2004, I 25:65 I-66 I.

31. Goodchild RE, Kim CE, Dauer WT: Loss of the dystonia-associated protein torsinA selectively disrupts the neuronal nuclear envelope. Neuron 2005, 48:923-932.

32. Augood SJ, Martin DM, Ozelius LJ, Breakefield XO, Penney JB Jr., Standaert DG: Distribution of the mRNAs encoding torsinA and torsinB in the normal adult human brain. Ann Neurol 1999, 46:76I-769.

33. Playford ED, Fletcher NA, Sawle GV, Marsden CD, Brooks DJ: Striatal [I8F]dopa uptake in familial idiopathic dystonia. Brain 1993, II6 ( Pt 5): I191-II99.

34. Augood SJ, Hollingsworth Z, Albers DS, Yang L, Leung JC, Muller B, Klein C, Breakefield XO, Standaert DG: Dopamine transmission in DYTI dystonia: a biochemical and autoradiographical study. Neurology 2002, 59:445-448.

35. Ichinose H, Ohye T, Takahashi E, Seki N, Hori T, Segawa M, Nomura Y, Endo K, Tanaka H, Tsuji S, Fujita K, Nagatus T: Hereditary progressive dystonia with marked diurnal fluctuation caused by mutations in the GTP cyclohydrolase I gene. Nat Genet 1994, 8:236-242.

36. Nygaard TG, Wilhelmsen KC, Risch NJ, Brown DL, Trugman JM, Gilliam TC, Fahn S, Weeks DE: Linkage mapping of dopa-responsive dystonia (DRD) to chromosome I4q. Nat Genet 1993, 5:386-39l.

37. Bhatia KP, Marsden CD: The behavioural and motor consequences of focal lesions of the basal ganglia in man. Brain 1994, I I 7 ( Pt 4):859-876.

38. Munchau A, Mathen D, Cox T, Quinn NP, Marsden CD, Bhatia KP: Unilateral lesions of the globus pallidus: report of four patients presenting with focal or segmental dystonia. J Neurol Neurosurg Psychiatry 2000, 69:494-498.

39. Gimenez-Roldan S, Delgado G, Marin M, Villanueva JA, Mateo D: Hereditary torsion dystonia in gypsies. Adv Neurol 1988, 50:73-8I.

40. Khan NL, Wood NW, Bhatia KP: Autosomal recessive, DYT2 like primary torsion dystonia: a new family. Neurology 2003, 61:1801-1803.

41. Fletcher NA: The genetics of idiopathic torsion dystonia. J Med Genet 1990, 27:409-4I2. 
42. Ahmad F, Davis MB, Waddy HM, Oley CA, Marsden CD, Harding AE: Evidence for locus heterogeneity in autosomal dominant torsion dystonia. Genomics 1993, 15:9-12.

43. Parker N: Hereditary whispering dysphonia. J Neurol Neurosurg Psychiatry 1985, 48:218-224.

44. Almasy L, Bressman SB, Raymond D, Kramer PL, Greene PE, Heiman GA, Ford B, Yount J, de Leon D, Chouinard S, Saunders-Pullman R, Brin MF, Kapoor RP, Jones AC, Shen H, Fahn S, Risch NJ, Nygaard TG: Idiopathic torsion dystonia linked to chromosome 8 in two Mennonite families. Ann Neurol 1997, 42:670-673.

45. Leube B, Rudnicki D, Ratzlaff T, Kessler KR, Benecke R, Auburger G Idiopathic torsion dystonia: assignment of a gene to chromosome I8p in a German family with adult onset, autosomal dominant inheritance and purely focal distribution. Hum Mol Genet 1996, 5: 1673-1677.

46. Valente EM, Bentivoglio AR, Cassetta E, Dixon PH, Davis MB, Ferraris A, lalongo T, Frontali M, Wood NW, Albanese A: DYT I3, a nove primary torsion dystonia locus, maps to chromosome Ip36.13--36.32 in an Italian family with cranial-cervical or upper limb onset. Ann Neurol 200I, 49:362-366.

47. Kitada T, Asakawa S, Hattori $N$, Matsumine $H$, Yamamura $Y$ Minoshima S, Yokochi M, Mizuno Y, Shimizu N: Mutations in the parkin gene cause autosomal recessive juvenile parkinsonism. Nature 1998, 392:605-608.

48. Lucking CB, Durr A, Bonifati V, Vaughan J, De Michele G, Gasser T, Harhangi BS, Meco G, Denefle P, Wood NW, Agid Y, Brice A: Association between early-onset Parkinson's disease and mutations in the parkin gene. N Engl J Med 2000, 342:|560-I567.

49. Klein C, Brin MF, de Leon D, Limborska SA, Ivanova-Smolenskaya IA, Bressman SB, Friedman A, Markova ED, Risch NJ, Breakefield XO, Ozelius LJ: De novo mutations (GAG deletion) in the DYTI gene in two non-Jewish patients with early-onset dystonia. Hum Mol Genet 1998, 7: I I33-I I 36.

50. Hjermind LE, Werdelin LM, Sorensen SA: Inherited and de novo mutations in sporadic cases of DYTI-dystonia. Eur J Hum Genet 2002, 10:213-216.

5I. Rechitsky S, Verlinsky O, Kuliev A, Ozen S, Laziuk K, Beck R, Gleicher $\mathrm{N}$, Verlinsky Y: Preimplantation genetic diagnosis for earlyonset torsion dystonia. Reprod Biomed Online 2004, 8:224-228.

52. Segawa M: Hereditary progressive dystonia with marked diurnal fluctuation. Brain Dev 2000, 22 Suppl I:S65-80.

53. Burke RE, Fahn S, Marsden CD: Torsion dystonia: a double-blind, prospective trial of high-dosage trihexyphenidyl. Neurology 1986, 36:160-164.

54. Walker RH, Danisi FO, Swope DM, Goodman RR, Germano IM, Brin MF: Intrathecal baclofen for dystonia: benefits and complications during six years of experience. Mov Disord 2000, I 5: | 242-1247.

55. Jankovic J: Dystonia: medical therapy and botulinum toxin. Adv Neurol 2004, 94:275-286.

56. Vercueil L, Krack P, Pollak P: Results of deep brain stimulation for dystonia: a critical reappraisal. Mov Disord 2002, I 7 Suppl 3:S89-93.

57. Vidailhet M, Vercueil L, Houeto JL, Krystkowiak P, Benabid AL, Cornu P, Lagrange C, Tezenas du Montcel S, Dormont D, Grand S, Blond S, Detante O, Pillon B, Ardouin C, Agid Y, Destee A, Pollak P: Bilateral deep-brain stimulation of the globus pallidus in primary generalized dystonia. N Engl J Med 2005, 352:459-467.

58. Anca MH, Zaccai TF, Badarna S, Lozano AM, Lang AE, Giladi N: Natural history of Oppenheim's dystonia (DYTI) in Israel. J Child Neurol 2003, I 8:325-330.
Publish with Bio Med Central and every scientist can read your work free of charge

"BioMed Central will be the most significant development for disseminating the results of biomedical research in our lifetime. "

Sir Paul Nurse, Cancer Research UK

Your research papers will be:

- available free of charge to the entire biomedical community

- peer reviewed and published immediately upon acceptance

- cited in PubMed and archived on PubMed Central

- yours - you keep the copyright
BioMedcentral 